\title{
The origin of porphyritic granite in Dongping gold deposit, Northern Hebei, China: Evidences from chronology and fluid inclusions*
}

Xu JiuhuA ${ }^{1}$, Wei HaO ${ }^{2}$, Chu HaIXIA ${ }^{3}$, Zhang GuORUi ${ }^{4}$

${ }^{1}$ University of Science and Technology Beijing, Beijing 100083, China (*jiuhuaxu@ces.ustb.edu.cn)

${ }^{2}$ Hebei Geouniversity, Shijiazhuang, China

${ }^{3}$ China University of Geosciences, Beijing 100083, China

${ }^{4}$ East China university of technology

The Dongping gold deposit is one of the large gold deposits in the North China Craton, which occurs in the host Devonian alkaline complex and are composed of a series of gold-bearing quartz veins and potassic altered ores. A porphyritic granite related with gold mineralization occurs in a NEE-SWW striking shearing zone within the alkaline complex, the origin of which is still unclear. The porphyritic quartz grains are rounded/sub-rounded, surrounded by fine recrystallized quartz grains and feldspar. Tiny stripe feldspar composed of albite and orthoclase occur as solid inclusions within grains of porphyritic quartz. Gold mineralization occurs in the intensive deformation and silicification zone within the porphyritic granite.

The zircon $\mathrm{U}-\mathrm{Pb}$ dating shows that the porphyritic granite has a concordant age of $142.02 \pm 1.2 \mathrm{Ma}$ and weighted mean age of $142.06 \pm 0.84 \mathrm{Ma}$. The Ar-Ar ages of orthoclase in porphyritic granite are $144.27 \pm 0.63 \mathrm{Ma}$ and $148.17 \pm 0.77 \mathrm{Ma}$ (plateau ages), and $145.43 \pm 1.11 \mathrm{Ma}$ and $146.67 \pm 1.53 \mathrm{Ma}$ (isochronal ages). A great numbers of fluid inclusions can be observed in porphyritic quartz of the porphyritic granite. They show various types: $\mathrm{L}-\mathrm{V}$ aqueous, $\mathrm{V}-\mathrm{L}, \mathrm{H}_{2} \mathrm{O}-\mathrm{CO}_{2}$, and occasionally L-V-S (halite-bearing) inclusions. The first generation of isolate or random L-V or V-L inclusions have relatively higher $T \mathrm{~h}_{\text {,tot }}\left(321{ }^{\circ} \mathrm{C}-400{ }^{\circ} \mathrm{C}\right)$, which may be considered to be primary and coeval to the formation of porphyritic quartz. Several suspected melt inclusions in porphyritic quartz were confirmed by carefully petrography and using muffle method. Because that the suspected melt inclusions are rarely seen in quartz phenocrysts, we conjecture that the original fluid during formation of porphyritic granite could be a super critical fluids or a meltfluid mixture. According to zircon $\mathrm{U}-\mathrm{Pb}$ dating and $\mathrm{Ar}-\mathrm{Ar}$ ages of orthoclase, the porphyritic granite might be originated from residual of Jurassic granite in the south of mine area.

* Funded by NSFC (41672070). 